\title{
UNIVERSITY OF MICHIGAN RADIOCARBON DATES XI
}

\author{
H. R. CRANE and JAMES B. GRIFFIN
}

The University of Michigan, Ann Arbor, Michigan

The following is a list of dates obtained since the time of the compilation of List X in December 1964. The method is essentially the same as that used for the work described in the previous list. Two $\mathrm{CO}_{2}-\mathrm{CS}_{2}$ Geiger counter systems are used. The equipment and counting techniques have been described elsewhere (Crane, 1961). The dates and estimates of error in this list follow the practice recommended by the International Radiocarbon Dating Conferences of 1962 and 1965, in that (a) dates are computed on the basis of the Libby half-life, $5570 \mathrm{yr}$, (b) A.D. 1950 is used as the zero of the age scale, and (c) the errors quoted are the standard deviations obtained from the numbers of counts only. In previous Michigan date lists up to and including VII we have quoted errors at least twice as great as the statistical errors of counting, in order to take account of other errors in the over-all process. If the reader wishes to obtain a standard deviation figure which will allow ample room for the many sources of error in the dating process, we suggest he double the figures that are given in this list.

We wish to acknowledge the help of Patricia Dahlstrom in preparing chemical samples and David M. Griffin in preparing the descriptions.

GEOLOGIC SAMPLES

\section{9450 B.c.}

Tusk of mammoth (Mammuthus jeffersoni), from Clayton Twp. $42^{\circ} 58^{\prime} \mathrm{N}$ Lat, $83^{\circ} 58^{\prime} \mathrm{W}$ Long), Sec. 31, T7N, R5E, Genesee Co., Michigan. Found at $12 \mathrm{ft}$ depth in calcareous clay, overlain by layer of sand, then layer of peat. Coll. 1962 by Biology Dept., Flint Community Junior College; subm. by G. A. Buck, Biology Dept., Flint Community Junior College, Flint, Michigan. Comment (G.A.B.): date established by pollen analysis agrees substantially with above date (Oltz and Kapp, 1963).

\section{M-1282. Pre-Lake Nipissing Shoreline, Michigan 4320 в.c.}

Wood chips and twigs of northern white cedar (Thuja occidentalis) id. by H. I. Mitchell, U. S. Forest Service, from Pre-Lake Michigan shoreline (45 $25^{\prime} \mathrm{N}$ Lat, $84^{\circ} 35^{\prime} \mathrm{W}$ Long), Cheboygan Co., Michigan. Location is $800 \mathrm{ft} \mathrm{S}$ of $\mathrm{N}$ section line and $1700 \mathrm{ft} \mathrm{E}$ of W section line, Sec. 25, T35N, R3W. Site is located on N-sloping forest-covered sandy beach of Pre-Lake Nipissing shoreline bordering $\mathrm{S}$ end of Burt Lake. Nipissing shoreline is ca. $500 \mathrm{ft} \mathrm{S}$ of collection site. Material was coll. from depth of 23 to $25 \mathrm{ft}$ below land surface, which is 610 to $615 \mathrm{ft}$ above sealevel; i.e., wood chips were 585 to $590 \mathrm{ft}$. Coll. 1961 and subm. by J. R. Byer- 
lay, Dept. of Conserv., Lansing, Michigan. Comment (J.R.B.): sample probably deposited during one of series of successively higher stages between Lake Chippewa and Lake Nipissing.

\section{M-1375. Todd Harbor (docksite), Michigan $\quad 3360 \pm 150$}

Wood (Larix laricina), from Todd Harbor docksite $\left(48^{\circ} 00^{\prime} 30^{\prime \prime} \mathrm{N}\right.$ Lat, $88^{\circ} 45^{\prime} 50^{\prime \prime}$ W Long), Isle Royale, Michigan. Overlain by "hardpan" several in. thick with 6 to $8 \mathrm{ft}$ of silt over that, and $8 \mathrm{ft}$ of water over silt. Date may assist in determining previous level of Lake Superior lower than present lake level. Coll. 1958 by R. M. Johnson; subm. by Robert Lind, Natl. Park Service, Houghton, Michigan. Comment (J.B.G.): date places sample between Nipissing and Algoma Lake stages.

\section{Dunlavy Lake Bog series, Michigan}

Wood and peat from S side of Dunlavy Lake Bog $\left(42^{\circ} 25^{\prime} 30^{\prime \prime} \mathrm{N}\right.$ Lat, $83^{\circ} 52^{\prime} 00^{\prime \prime} \mathrm{W}$ Long), located in Huron Valley, $6.5 \mathrm{mi} \mathrm{N}$ of Dexter, $\mathrm{SW}_{1 / 4} \mathrm{NW}_{1 / 4}$ Sec. 33, T1N, R5E, Hamburg, Twp., Livingstone Co., Michigan. This middle reach of the Huron River Valley is dammed by glacial and peat deposits into series of small, bog-bordered lakes. Peat section contains no evidence of stream erosion or flooding, implying that peat deposit surface was always outside or above active river channels. From fossil pollen. to be descr. by Benninghoff, it is clear that base of this section was deposited early in post-ice spruce forest period, and that deposition continued until ca. 100 yr ago. Coll. 1962 by W. S. Benninghoff and D. F. Eschman; subm. by W. S. Benninghoff, Dept. of Botany, Univ. of Michigan.

M-1459. Dunlavy Lake Bog, 200 to $210 \mathrm{~cm}$. $8630 \pm 300$

Log fragments from 200 to $210 \mathrm{~cm}$. thick. Taken from cleaned wall of trench excavated by dragline for that purpose. Sample believed to be middle Hypsithermal in age.

M-1460. Dunlavy Lake Bog, 150 to $165 \mathrm{~cm}$ depth $7120 \pm 220$

Block of peat from 150 to $165 \mathrm{~cm}$ depth from cleaned wall of trench. Comment (W.S.B.): pollen still under study. Dates seem reasonable.

\section{Galien River Terrace series, Michigan}

Hardwood and nut shells from Galien River Terrace $\left(41^{\circ} 51^{\prime} \mathrm{N}\right.$ Lat, $86^{\circ} 33^{\prime} \mathrm{W}$ Long), S of New Troy, SE $1 / 4$ NW1/4 Sec. 17, T7N, R19W, Weesaw Township, Berrien Co., Michigan. At sampling point, river near end of its $\mathrm{N}$ course. Immediately downstream it turns toward $\mathrm{W}$ for $2 \mathrm{mi}$, then SW for $81 / 2 \mathrm{mi}$, until it cuts through shore dunes to empty in Lake Michigan. Nipissing rise of Lake Michigan may have caused dune field to impede river's drainage at same time base level was rising, and this may have been responsible for construction of $6 \mathrm{ft}$ terrace $\mathrm{S}$ of 
New Troy. Samples found in buried forest bed, probably representing major flood near close of Lake Michigan rise to Nipissing level. If so, samples should date 4500 B.P. Coll. 1962 by Paul Randall; subm. by W. S. Benninghoff, Univ. of Michigan.

\section{M-1461. Galien River Terrace}

$3090 \pm 160$

Shells of Juglans cinerea and Juglans nigra from buried forest bed in low terrace, surface of which is $6 \mathrm{ft}$ above mean level of Galien River. Forest bed is $1 \mathrm{ft}$ above river level and 1 to $2 \mathrm{ft}$ thick, resting on cobbly gravel and overlain by coarse sand with pebbles.

\section{M-1462. Galien River Terrace}

$2370 \pm 130$

420 B.c.

Hardwood log fragments from buried forest bed in low terrace of Galien river. Comment (W.S.B.): it is likely that interpretation of forest bed as a relic of rise of Lake Michigan to Nipissing level is not correct.

\section{M-1603. Krutsch site, Michigan}

$11,800 \pm 400$ 9850 B.C.

Black spruce wood fragments from Krutsch site $\left(43^{\circ} 24^{\prime} 25^{\prime \prime} \mathrm{N}\right.$ Lat, $84^{\circ} 03^{\prime} 45^{\prime \prime} \mathrm{W}$ Long), SW1/4 NW1/4 Sec. 36, Saginaw Co., Michigan. Sample chopped from black spruce stump in buried forest bed at 605 $\mathrm{ft}$ alt, overlain by complex dune-soil sequence. Should be of Two Creeks age or ca. 10 to 11,500 B.c. Less probably, might be pre-Nipissing or ca. 2000 B.c. (Hough, 1963). Coll. 1964 and subm. by H. T. Wright, for Mus. of Anthropol., Univ. of Michigan. Comment (H.T.W.): date tends to confirm the Two Creeks age established by Broecker and Farrand (1963).

\section{M-1604. Dodge Park Dump site, Michigan}

$5300 \pm 200$

3350 B.C.

Twigs and small branch fragments from Dodge Park Dump site (42 $35^{\prime} 30^{\prime \prime} \mathrm{N}$ Lat, 83 $00^{\prime} 30^{\prime \prime} \mathrm{W}$ Long), NE1/4 SW1/4 NW1/4 Sec. 14, Stealing Township, MaComb Co., Michigan. Sample overlain by sand, near floor of peat-filled channel cut into estuarine terrace which tops at $605 \mathrm{ft}$ alt (Hough, 1963; Dreimanis, 1964)). Coll. 1964 and subm. by $\mathrm{H}$. T. Wright, for Mus. of Anthropol., Univ. of Michigan. Comment (H.T.W.): compares favorably with date obtained on log from same site (M-1635, this list).

\section{M-1635. Dodge Park Dump site, Michigan}

$5800 \pm 200$

$\mathbf{3 8 5 0}$ B.C.

Fragment of large log from the Dodge Park Dump site $\left(42^{\circ} 35^{\prime} 30^{\prime \prime}\right.$ N Lat, $83^{\circ} 00^{\prime} 30^{\prime \prime}$ W Long), NE1/4 SW1/4 NW1/4 Sec. 14, Sterling Township, MaComb Co., Michigan. From lower peat level of a peat-filled river channel. Lower peat is separated from upper peat by cross-bedded sands. Entire channel is overlain by pond sediments (Hough, 1963; Dreimanis, 1964). Coll. 1964 by Jerry DeVisscher; subm. by J. E. Fitting, Mus. of 
Anthropol., Univ. of Michigan. Comment (J.E.F.): this sample, along with M-1604, probably dates an interval of slight lake level drop during general rise of Nipissing stage in area.

\section{M-1626. Meilock Road sandpit, Miehigan}

$11,800 \pm 350$

9850 B.C.

Unburned wood from Mielock Road sandpit $\left(44^{\circ} 02^{\prime} \mathrm{N}\right.$ Lat, $83^{\circ}$ 32' W Long), SW $1 / 4$ SW1/4 Sec. 15, T21N, R7E, Iosco Co., Michigan. From stump in buried forest fixed in peat layer under beach believed to be either Nipissing or Algonquin. Strong podzol development on beach favors interpretation as Algonquin, but precise alt is not known. Also dates large body of plant remains, identification of which will contribute to understanding of post-Pleistocene ecology of Upper Great Lakes. Coll. 1964 and subm. by H. T. Wright for Mus. of Anthropol., Univ., of Michigan. Comment (H.T.W.): date conforms to Two Creeks age of Broecker and Farrand (1963).

\section{Skeldal series, NE Greenland}

Shells, id. by H. G. Richards, Acad. Natl. Sci., Philadelphia, at various altitudes from emerged marine deposits and from fjord deposit (Yale VII; Washburn and Stuiver, 1962), and a peat deposit in Skeldal $\left(72^{\circ}\right.$ $15^{\prime} \mathrm{N}$ Lat, 24 $15^{\prime} \mathrm{W}$ Long), Mesters Vig district, SW side of Kong Oscars Fjord, NE Greenland, ca. $70 \mathrm{~km}$ from entrance. Samples provide information for establishing glacial chronology, and for determining rate and amount of crustal uplift in district. N.B. For comparative purposes, shell dates have been corrected by subtracting $550 \pm 70 \mathrm{yr}$, age of modern shells (Y-606) from same locality (Yale VII). Coll. 1963 and subm. by N. P. Lasca, Dept. of Geology-Mineralogy, Univ. of Michigan.

\section{M-1611. Skeldal $31 \mathrm{~m}$}

$7190 \pm 250$

5240 B.C.

Mya truncata Linné and Macoma calcarea (Gmelin) from Location 1 at alt of $31 \pm 2 \mathrm{~m}, \mathrm{E}$ cut bank emerged delta in soliflucted fjord-bottom material, E side Skelelv, ca. $2.5 \mathrm{~km}$ down valley from waterfalls, and 4 $\mathrm{km} \mathrm{S}$ of Skelhytte.

\section{M-1612. Skeldal 59 to $60 \mathrm{~m}$}

$7940 \pm 300$

Hiatella arctica (Linné) and Mya truncata from Location 2, at alt of 59 to $60 \pm 2 \mathrm{~m}$, ca. $0.4 \mathrm{~km} \mathrm{E}$ of Location 1, NW bank emerged delta, E side Skelelv, in situ.

\section{M-1613. Skeldal 59 to $60 \mathrm{~m}$}

$8290 \pm 300$

6340 в.c.

Macoma calcarea, Hiatella arctica and Mya truncata from Location 3 , at alt of 59 to $60 \pm 2 \mathrm{~m}$, SE cut bank emerged delta, $1 \mathrm{~km} \mathrm{~W}$ of Location 2, W side Skelelv, in situ. 


\section{M-1614. Skeldal $14 \mathrm{~m}$}

Macoma sp., Hiatella arctica, and Mya truncata from Location 4 at alt of $14 \pm 1 \mathrm{~m}$, SE cut bank emerged delta W side Skelelv at Kong Oscars Fjord, in situ.

\section{M-1615. Skeldal $59 \mathrm{~m}$}

$8590 \pm 300$

Mya truncata and Hiatella arctica from Location 5 at alt of $59 \pm 2$ $\mathrm{m}, \mathrm{N}$ face of bank cut by tributary, in soliflucted material of fjordbottom and delta, W side Skelelv, ca. $1.5 \mathrm{~km}$ up valley from Location 4 .

M-1616. Skeldal $36 \mathrm{~m}$

$7220 \pm 250$

5270 B.c.

Mya truncata from Location 6 at alt of $36 \pm 2 \mathrm{~m}$, N face of strandline, $\mathrm{W}$ side Skeldal, ca. $1.2 \mathrm{~km}$ up valley from Location 4 , in situ.

\section{M-1617. Skeldal $21 \mathrm{~m}$}

$6410 \pm 220$

\section{0 в.c.}

Hiatella arctica, Mya truncata, Macoma calcarea, and Mytilus edulis Linné from Location 7 , at alt of $21 \pm 1 \mathrm{~m}$, strandline $\mathrm{W}$ side Skelelv, ca. $1 \mathrm{~km}$ up valley from Location 4 , in situ.

\section{M-1618. Skeldal 20 to $21 \mathrm{~m}$}

$6720 \pm 250$

4770 в.c.

Hitella arctica, Mya truncata, and Astarte sp., from Location 8 at alt of 20 to $21 \pm 1 \mathrm{~m}$, NW cut bank emerged delta E side Skelelv, ca. 1 $\mathrm{km} \mathrm{SW}$ of Skelhytte, in situ.

\section{M-1619. Skeldal $4 \mathrm{~m}$}

$5430 \pm 200$

Macoma calcarea, Mya truncata, Mya arenaria, and Hiatella arctica from Location 9 at alt of $4 \pm 0.5 \mathrm{~m}, \mathrm{NW}$ cut bank emerged delta, ca. 4.5 $\mathrm{km}$ SE of Skelhytte, SW side Kong Oscars Fjord, in situ.

\section{M-1620. Skeldal $17 \mathrm{~m}$}

$6280 \pm 200$

Mya truncata and Macoma calcarea from Location 10 at alt of $17 \pm 1 \mathrm{~m}$, NW cut bank emerged delta ca. $1.5 \mathrm{~km}$ SE of Skelhytte on SW side Kong Oscars Fjord, in situ.

\section{M-1621. Skeldal 3 to $4 \mathrm{~m}$}

$5130 \pm 200$

Astarte sp., Macoma sp., Serripes grenlandicus (Bruguière), Mya truncata, M. arenaria, and Mytilus edulis from Location 11 at alt of 3 to $4 \pm 0.5 \mathrm{~m}$, NW cut bank emerged delta SE side Skelelv at entrance to Kong Oscars Fjord, in situ.

M-1622. Skeldal $11 \mathrm{~m}$

$6610 \pm 250$

Hiatella arctica and Mya truncata from Location 12 at alt of $11 \pm 1$ $\mathrm{m}, \mathrm{NE}$ cut bank emerged delta, ca. $0.7 \mathrm{~km} \mathrm{E}$ of Skelelv on SW side Kong Oscars Fjord, in situ. 
M-1623. Skeldal 9 m

Hiatella arctica and Mya truncata from Location 13 at alt of $9 \pm 1$ m, NW cut bank emerged delta SE side Skelelv at entrance to Kong Oscars Fjord, in situ.

\title{
M-1624. Skeldal $51 \mathrm{~m}$
}

$4930 \pm 200$

Peat deposit from Location 14, $1.45 \mathrm{~m}$ below surface, overlain by interbedded sands, silts, and pebble gravel at alt of $51 \pm 2 \mathrm{~m}$, $\mathrm{S}$ exposure cut bank in lacustrine sediments, E side Skelelv, ca. $7 \mathrm{~km} \mathrm{~S}$ of Skelhytte. Comment (N.P.L.): dates satisfactory; to be discussed elsewhere.

\author{
ARCHAEOLOGICAL SAMPLES \\ Upper Mississippi, Great Lakes
}

\section{Norton mound series, Michigan}

Charcoal and ash from Norton mounds $\left(42^{\circ} 54^{\prime} 42^{\prime \prime} \mathrm{N}\right.$ Lat, $85^{\circ} 43^{\prime}$ $36^{\prime \prime}$ W Long), Kent Co., Michigan. Dates from Mound $\mathrm{H}$ should date construction of mound in which the burial included one extended female, one bundled adult male, three juveniles, and ceramics resembling those from Utica mounds. Date from Mound C should predate construction of mound. Coll. 1963 and subm. by R. E. Flanders for Mus. of Anthropol., Univ. of Michigan.

\section{M-1488. Norton Mound $H$}

$$
1790 \pm 120
$$

$$
\text { A.D. } 160
$$

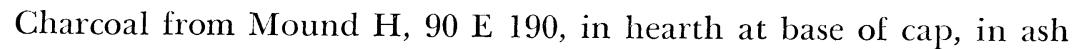
lens, and immediately above black dirt from burial pit, $5 \mathrm{ft} S$ of pit.

\section{M-1489. Norton Mound $H$}

Ash and charcoal from Mound $\mathrm{H}$, ash lens below cap, $3 \mathrm{ft} \mathrm{E}$ of pit.

\section{M-1490. Norton Mound $H$}

$$
1850 \pm 100
$$

Ash from Mound $\mathrm{H}$, at base of cap, $5 \mathrm{ft} \mathrm{N}$ of burial pit.

\section{M-1493. Norton Mound C}

$$
1960 \pm 120
$$

Charcoal from Mound $\mathrm{C}$ in hearth area on original land surface $\mathrm{W}$ of burial. Hearth overlain by artificial layer of clay, then mound fill. Associated with charcoal was burned animal bone, pottery, and shell. General Comment (J.B.G.): three of four dates are acceptable but M1489 is ca. 900 yr too late.

\section{M-1519. Sissung Farm site (20 Mr-30), Michigan A.D. 700}

$$
1250 \pm 120
$$

Charcoal from Sissung Farm site (20 Mr-30) $\left(42^{\circ} 05^{\prime} \mathrm{N}\right.$ Lat, $83^{\circ} 30^{\prime}$ W Long), Monroe Co., Michigan. From Feature 1, Test Pit B-2 contain- 
ing ceramic material similar to earlier horizon at Riviere au Vase, a transitional stage in this area between Middle and Late Woodland. Coll. by G. R. Peske; subm. by J. E. Fitting. Comment (J.E.F.): previous estimates for duration of Riviere au Vase phase of Younge tradition (Fitting, 1965) were too conservative. Because this date and several others have consistently run about a century earlier than originally expected, entire dating for Younge tradition has been revised (Fitting, in press). It should be noted that corn was found in this feature.

\section{M-1520. Verchave I ( 20 Mb-178), Michigan A.D. 1320}

$630 \pm 100$

Charcoal from Verchave I (20 Mb-178) (420 $34^{\prime} \mathrm{N}$ Lat, $82^{\circ} 50^{\prime} \mathrm{W}$ Long), Harrison Twp., T2N, R14E, Macomb Co., Michigan. From Feature 2 in Unit $500 \mathrm{E} 200$, Late Woodland refuse pit containing plain, smoothed, fine-tempered sherds of type believed to be late in area. One Madison point also came from pit (Fitting, 1965). Coll. 1962 and subm. by J. E. Fitting. Comment (J.E.F.): since bulk of material from site can be attributed to Wolf phase of Younge tradition, including material in this feature, I believe this is an accurate date for Wolf Phase. It is earlier than A.D. 1400 which I had suggested (Fitting, 1965) for beginning of Wolf phase and, along with other consistently earlier than expected dates, has led to a chronological revision for Younge tradition (Fitting, in press).

\section{Green Point (Schultz) site series, Michigan}

Charcoal and hickory nuts from Green Point (Schultz) site (20 Sa-2), (42 $23^{\prime} \mathrm{N}$ Lat, $83^{\circ} 59^{\prime} \mathrm{W}$ Long), S1/2 NE1/4 Sec. 3, T11N R4E, Saginaw Co., Michigan. From lower dark silts, compare with M-1432 for similar Early Woodland cultural horizon and with M-1433 (Michigan XII) for overlying Middle Woodland occupation with a sterile medium brown silt separating the two. Coll. 1963 and subm. by D. W. Taggart, for Mus. of Anthropol., Univ. of Michigan.

\section{M-1524. Green Point (Schultz) site, Feature 48}

Charcoal, predominantly Carya and some Quercus, Salix, Prunus, and Ulmus, and hickory nut shells from Feature 48 at depth of $11 / 2 \mathrm{ft}$ in top of lower dark silts. Associated with 10 sherds from vessel: thick, interior-exterior cordmarked, straight vertical rim and flattened base.

\section{M-1525. Green Point (Schultz) site, Feature $62 \quad 530$ B.c. \\ $2480 \pm 150$}

Charcoal, mostly Quercus and Carya and some Salix, Prunus, Alnus, and Ulmus from Feature 62, $2.2 \mathrm{ft}$ below surface in lower dark silts. Associated with 2 thick, interior cordmarked potsherds and Early Woodland occupation floor.

General Comment (D.W.T.): dates appear entirely adequate. These, in combination with M-1432, all from sealed deposits, serve to date rather 
definitely the Early Woodland Schultz component at ca. 530 B.c. Likewise, by associated chert and projectile point types, they inferentially date Late Pomranky burial complex as expressed at Pomranky, Hodges, and Stroebel burials (Binford, 1963a, 1963b). To my knowledge, these dates represent only $\mathrm{C}^{14}$ dates obtained in direct association with thick, interior cordmarked pottery in NE United States.

\section{M-1625. Goodwin-Gresham site, Michigan}

$1340 \pm 110$

Wood charcoal and cooking debris from Goodwin-Gresham site (42 $16^{\prime} \mathrm{N}$ Lat, $83^{\circ} 20^{\prime} \mathrm{W}$ Long), NE $1 / 4$ SW $1 / 4$ Sec. 34, T23N, R9E, Iosco Co., Michigan. Sample from Feature 12, a hearth $0.9 \mathrm{ft}$ below present surface. Hearth at base of red-brown sandy occupation zone 0.6 $\mathrm{ft}$ thick. Associated material indicates Late Point Peninsula tradition. Coll. 1964 and subm. by H. T. Wright for Mus. of Anthropol., Univ. of Michigan. Comment (J.B.G.): date is acceptable and conforms with other reasonable Late Point Peninsula time estimates.

\section{M-1640. Lookout site, Isle Royale, Michigan}

A.D. 1510

$$
440 \pm 100
$$

Wood from Lookout site ( $48^{\circ} 09^{\prime} 43^{\prime \prime} \mathrm{N}$ Lat, $88^{\circ} 29^{\prime} 06^{\prime \prime} \mathrm{W}$ Long), Isle Royale, Michigan. Site $225 \mathrm{ft}$ above Lake Superior on Greenstone Ridge near Monument Rock. Sample found $2.6 \mathrm{ft}$ below surface of fill in Pit 4. A possible aid in determining length of time taken to fill pit with debris (Michigan X). Coll. 1960 by Tyler Bastian; subm. by J. B. Griffin, Univ. of Michigan. Comment (J.B.G.): apparently one of latest pits of Isle Royale Copper workings.

\section{Steed-Kisker site series, Missouri}

Charcoal from Steed-Kisker site $\left(39^{\circ} 17^{\prime} 15^{\prime \prime} \mathrm{N}\right.$ Lat, 94 $49^{\circ} 30^{\prime \prime} \mathrm{W}$ Long), center of W edge Sec. 27, T52N, R35W, Platte Co., Missouri. This is type site of Steed-Kisker focus in W Missouri (Wedel, 1943). Coll. 1962 and subm. by J. M. Shippee, Univ. of Missouri.

\section{M-1395B. Steed-Kisker midden deposit A.D. 1000}

Charcoal and charred corncob and kernels from 12 to 24 in. deep in midden deposit of general refuse from semi-subterranean lodges on slope midway between village site and cemetery described by Wedel.

\section{M-1396. Steed-Kisker post mold, House 3 A.D. 1900}

$\mathbf{5 0} \pm \mathbf{1 0 0}$

Charcoal from large posthole near fireplace of House 3.

M-1397. Steed-Kisker fireplace, House 3

Charcoal from saucer-shaped fireplace of House 3. Material recovered from house included polished stone pipe, clay pipe, 12 restorable 
pottery vessels of typical Steed-Kisker shapes and decoration, projectile points, scrapers, and sandstone abraders.

\section{M-1398. Steed-Kisker roasting pit}

$740 \pm 110$

Charcoal from pit $39 \mathrm{in}$. wide and $14 \mathrm{in.} \mathrm{deep} \mathrm{containing} \mathrm{fired} \mathrm{lime-}$ stone and charcoal at depth of $10 \mathrm{in}$. Pit was outside and on uphill side of House 3.

General Comment (J.B.G.): except for M-1396, which was too small for a completely satisfactory run, dates seem reasonable for this Mississippian complex and may well bracket time of occupation.

\section{M-1356. Klunk Mound 10, Illinois}

$1170 \pm 120$

Charcoal, red cedar (Junipernus virginiana) and some black walnut, id. by R. Yarnell, from Klunk Mound $10\left(39^{\circ} 12^{\prime} 35^{\prime \prime} \mathrm{N}\right.$ Lat, 90 $32^{\prime}$ $48^{\prime \prime}$ W Long), Calhoun Co., Illinois. Sample from crematory A in small mound containing 2 crematories. Crematory A was $81 / 2 \mathrm{ft}$ in diam and 24 in. deep from mound surface to crematory floor. Charcoal was associated with 3 burials, a crude baked clay pipe, Canteen Cordmarked sherds, and portion of charred bone pendant. Should date construction of three Klunk Mounds with 7 crematories in and outside Mounds 8, 9 and 10, possibly preceding Mississippian-influenced Jersey Bluff culture. Coll. 1961 and subm. by Gregory Perino, Thm. Gilcrease Found., Tulsa, Oklahoma. Comment (G.P.): this mound and its two crematories should fit into same time period, ca. A.D. 600, as Klunk Mound 8, dated and described in Michigan IX (p. 6).

\section{M-1357. Koster Mound 2, Illinois}

$1300 \pm 120$

Charred human bone from Koster Mound $2\left(39^{\circ} 12^{\prime} 35^{\prime \prime} \mathrm{N}\right.$ Lat, $90^{\circ} 32^{\prime} 48^{\prime \prime}$ W Long), Greene Co., Illinois. Sample from Burial 2, male skeleton lying on original ground surface under $\mathrm{W}$ edge of mound and 6 in. from surface. Should date construction of Koster mounds and occupation of village site within Late Woodland framework of area. Coll. 1961 and subm. by Gregory Perino. Comment (G.P.): only date available from seven Koster mounds and is from lone cremation found. Typologically, burials from this site should date after Klunk Mounds 8 and 10 dates as indicated by discovery of Late Woodland discoidal and semi-flexed burials. Earlier Klunk burials were flexed or cremated. Eleven Koster burials contained one or more corner-notched arrow points in vital areas, indicating considerable local conflict among tribes, perhaps at beginning of Mississippi infiltration.

\section{Schild site series, Illinois}

Charcoal from Schild site $\left(39^{\circ} 14^{\prime} 15^{\prime \prime} \mathrm{N}\right.$ Lat, $90^{\circ} 32^{\prime} 57^{\prime \prime} \mathrm{W}$ Long), Greene Co., Illinois. Site consists of cemetery on two knolls on bluff overlooking Illinois River Valley. Burials apparently were those of 
acculturated Late Woodland (Jersey Bluff), Mississippian group on Old Village time level. Coll. 1962 and subm. by Gregory Perino.

M-1393. Schild site, Knoll B, Burial 275

$$
1020 \pm 110
$$

Charred wood from Knoll B, Burial 275 consisting of bundle of charred human bone and various burned and charred artifacts. All were at depth of 14 to 16 in. on $\mathrm{E}$ end of Knoll $\mathrm{B}$.

\section{M-1394A. Schild site, Knoll A, Burial 122 A.D. 1200}

$750 \pm 110$

Charred wood from Knoll A, Burial 122, consisting of partly charred remains of child, articulated remains of two adults, each burial having been placed on top of a lower one.

General Comment (G.P.): dates from Schild site seem to have bracketed age limits for Old Village including acculturation period. Average of these dates would produce reasonable figure for date of site.

\section{Peisker site series, Illinois}

Charcoal and antler from Peisker site $\left(39^{\circ} 5^{\prime} 26^{\prime \prime} \mathrm{N}\right.$ Lat, 90 $35^{\prime}$ 46" W Long), Calhoun Co., Illinois. Coll. 1962 by Gregory Perino; subm. by Stuart Struever, Dept. of Anthropol., Univ. of Chicago.

\section{M1403. Peisker site, Mound 1}

$2180 \pm 130$

230 B.C.

Charcoal from charcoal mass (Feature 20) situated in sand ridge beneath Peisker Mound 1. Occurring at surface of sand ridge. Feature is associated with latest premound occupation of sand ridge and this would give it an early to middle Havana affiliation.

\section{M-1404. Peisker site, Mound 2}

Charcoal occurring as mottling throughout fill of pit (Feature 4), located in sand ridge beneath Peisker Mound 2 in SE quarter. Sand ridge yielded homogenous Black Sands artifact complex. Should be Early Woodland and date 550 to 650 B.c.

\section{M-1405. Peisker site, Mound 2}

$1770 \pm 130$

Carbonized wood and antler (Odocoileus virginianus) from shallow pit (Feature 7) located in sand ridge beneath Peisker Mound 2, SE quarter. Feature 7 occurred close to Burials 5, 6 and 7 and is regarded as probably associated with burial activity. Since sand ridge beneath Mound 2 yielded an homogenous Black Sands artifact complex, and burials clearly antedate mound itself, burials and Feature 7 have Early Woodland origin and should date 550 to 650 B.c.

General Comment (S.S.): date of 230 B.C. for early Havana occupation is reasonable but 325 B.c. for Early Woodland is later than expected. Date for M-1405 suggests that Feature 7 is associated with period of mound building instead of with Early Woodland. 


\section{Apple Creek site series, Illinois}

Charcoal from Apple Creek site $\left(39^{\circ} 22^{\prime} 15^{\prime \prime} \mathrm{N}\right.$ Lat, $90^{\circ} 32^{\prime} 22^{\prime \prime} \mathrm{W}$ Long), Greene Co., Illinois. Coll. 1962 and subm. by Stuart Struever.

\section{M-1406. Apple Creek site, pit (Feature 84c) A.D. 640}

$$
1310 \pm 100
$$

Wood-charcoal from ash-charcoal-burnt soil lens within storage refuse pit (Feature 84c). Soil lens, with concentration of burnt limestone fragments, is interpreted as residue of hearth redeposited in empty storage pit. Associated cultural materials belong to White Hall phase, a Late Havana manifestation according to Streuver, and may date A.D. 400 to 500 .

\section{M-1407. Apple Creek site, pit (Feature 203c) A.D. 790}

$1160 \pm 120$

Wood-charcoal from cylindrical storage refuse pit (Feature 203c), part of redeposited residue of hearth or roasting pit. Associated artifacts are affiliated with White Hall phase. Since it is Late Havana, it should date A.D. 400 to 550 .

\section{M-1408. Apple Creek site, pit (Unit 179d)}

$2660 \pm 130$

Wood-charcoal from charred mass at base of pit in provenience unit $179 \mathrm{~d}$, located in floor of house.

General Comment (S.S.): the early date for M-1408 is difficult to understand and does not apply to White Hall phase material with which charcoal was associated. Dates for White Hall phase of M-1406 and M-1407 are acceptable.

\section{M-1590. Vandruff's Island site, Illinois}

Charred wood from Vandruff's Island site (IAS No. Ri-22), $\left(41^{\circ}\right.$ $25^{\prime} 30^{\prime \prime} \mathrm{N}$ Lat, $90^{\circ} 30^{\prime} 45^{\prime \prime} \mathrm{W}$ Long), SE $1 / 4$ SE $1 / 4$ SE $1 / 4$ Sec. 14, T $17 \mathrm{~N}$, $\mathrm{R} 2 \mathrm{~W}$, on island in Rock River near Rock Island, Rock Island Co., Illinois. From Feature 41, 555-30W, a large cylindrical pit, bottom 5.5 $\mathrm{ft}$ below surface, distance $3.6 \mathrm{ft}$. Charcoal found in section 3.1 to $4.3 \mathrm{ft}$ below surface. Assemblage found at site is primarily Archaic although some Late Woodland sherds and some historic objects have been recovered. Oval houses occurred at site as did large storage (?) pits and concentrations of shell refuse. Coll. 1961 and 1962 and subm. by E. B. Herold, 2128 Frisco Dr., Davenport. Iowa. Comment (E.B.H.): date indicates association with historic Sauk occupation.

\section{M-1591. Wolf site, Illinois}

$$
1650 \pm 120
$$

Charred wood from Wolf site $\left(41^{\circ} 25^{\prime} 20^{\prime \prime} \mathrm{N}\right.$ Lat, $90^{\circ} 25^{\prime} 45^{\prime \prime} \mathrm{W}$ Long), SE1/4 SE1/4 SW1/4 Sec. 22, T17N, R1W, Rock Island Co., Illinois. Site on $\mathrm{E}$ side of Coal Creek at foot of bluff on $\mathrm{S}$ side of Rock River. Sample found in Feature 1, 95E-0, 0.8 to $2.0 \mathrm{ft}$ below surface of complex 
of several refuse pits. Associated pottery is similar to Weaver in decoration. Surface collections have also produced Middle Woodland material similar to Havana types. Oval houses found on site. Coll. 1963 by G. J. Fenner and E. B. Herold and subm. by E. B. Herold. Comment (E.B.H.): date is reasonable for this occupation.

\section{Lawrence site series, Illinois}

Charred wood from Lawrence site $\left(41^{\circ} 45^{\prime} 45^{\prime \prime} \mathrm{N}\right.$ Lat, $89^{\circ} 45^{\prime} \mathrm{W}$ Long), NE $1 / 4$ NE $1 / 4$ NE $1 / 4$ Sec. 36, T20N, R6E, Whiteside Co., Illinois. Site above flood plain on W side of Rock River. Fisher trailed pottery and other Upper Mississippian artifacts occurred in assemblage. Coll. 1963 by C. J. Bareis and E. B. Herold; subm. by E. B. Herold.

M-1592. Lawrence site, Feature 27

$780 \pm 110$

Charred wood from Feature 27, 109-33 E, basin-shaped refuse and firepit, $2.5 \mathrm{ft}$ in diam, $1.37 \mathrm{ft}$ deep below grader level.

M-1593. Lawrence site, Feature 59

A.D. 1160

$790 \pm 110$

Charred wood from Feature 59, 235 N-7 W, bell-shaped refuse pit, $3.5 \mathrm{ft}$ in diam, $0.9 \mathrm{ft}$ deep below grader level.

\section{M-1594. Lawrence site, Feature 16}

$690 \pm 110$

Charred wood from Feature 16, 98 N-25 E, slightly bell-shaped pit, $3.1 \mathrm{ft}$ in diam, $1.3 \mathrm{ft}$ below grader level.

M-1595. Lawrence site, Feature 39 A.D. 1270

$680 \pm 110$

Charred wood from Feature 39, $175 \mathrm{~N}-26 \mathrm{E}$, slightly undercut refuse pit, $3.1 \mathrm{ft}$ in diam, $1.5 \mathrm{ft}$ deep below grader level.

General Comment (E.B.H.): dates are consistent and satisfactory for this Upper Mississippi assemblage.

\section{M-1722. Loyd site, Illinois}

$430 \pm 100$

Charred corn kernels from Loyd site (38 $44^{\prime} 35^{\prime \prime} \mathrm{N}$ Lat, $90^{\circ} 00^{\prime}$ $15^{\prime \prime}$ W Long), Madison Co., Illinois. Sample from multi-component occupational site, Late Woodland and Mississippian, and found in Feature 48 , refuse pit cut by wall trenches of two Mississippian houses in house location occupied by sequence of four Mississippian houses. Pottery association of Feature 48 is Mississippian with slight mixing of small Woodland sherds; plain polished Tippets Bean Pot sherds and polished handle are present but no Cahokia Cordmarked or Wells Incised: two plain, low-rimmed jar sections are present but no Ramsey Incised. One sherd of foreign paste is polished and engraved. Pottery types missing from feature are found elsewhere at site. Should date early phase of Mississippian occupation of site, perhaps just prior to introduction of 
Cahokia Cordmarked pottery, and date of 700 to 800 в.P. is expected. Coll. 1963 by P. J. Munson; subm. by R. L. Hall, Illinois State Mus., Springfield, Illinois. Comment (R.L.H.): substantially later than expected.

\section{Monks Mound series, Illinois}

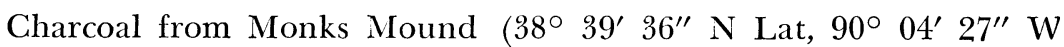
Long), SE1/4, SE $1 / 4, \mathrm{SE} 1 / 4$, Sec. 34, T3N, R9W, Madison Co., Illinois. Coll. 1964 and subm. by James Porter and C. J. Bareis, Univ. of Illinois.

\section{M-1636. Monks Mound, Feature 13}

Charcoal from fourth terrace in middle of $\mathrm{N}$ end of Feature 13. From N225 profile at E188.2, $160 \mathrm{~cm}$ below surface or 230 to $235 \mathrm{~cm}$ below arbitrary datum for mound top. Associated with second to last occupation and distinct prehistoric occupation surface.

\section{M-1637. Monks Mound, Feature 4}

$$
670 \pm 100
$$

Charcoal from Feature 4, burned floor of house, from N199,328 $\mathrm{E} 44,895,39$ to $42.5 \mathrm{~cm}$ below surface, on slope bordering (S side) of major ravine on $\mathrm{W}$ side. Associated underneath charcoal were three vessels, an undecorated Wells plate, an effigy bowl without its head, and a plain shattered vessel.

General Comment (J.P.): M-1636 is indicative of period just prior to last building phase of fourth terrace of Monks Mound. Dates fit very nicely within range of dates previously run for the Mitchell site, and indicates this satellite center was occupied during terminal phases of the Monks Mound area. M-163i falls very nicely within range of two dates previously run for the Collinsville Airport site. Feature 1 at that site dated A.D. 1135 to 1145 (M-1297) and also contained Cahokia Cordmarked sherds.

\section{Rogers site series, Kentucky}

Charcoal from Rogers site (BE 35-61), (39 $2^{\prime} 9^{\prime \prime} \mathrm{N}$ Lat, 84 $52^{\prime} 25^{\prime \prime}$ W Long), Boone Co., Kentucky. Site is composed of two different village areas located on second terrace overlooking Ohio River. Perhaps a Hopewell site, first to be found S of Ohio River. Possibly contemporary with Late Adena, as traits of both cultures exist at site. Coll. 1961 and subm. by Ellis Crawford, Wm. Behringer Memorial Mus., Covington, Kentucky.

M-1351. Rogers site, Pit 4

$$
1440 \pm 130
$$

Charcoal, chiefly red oak group, id. by R. Yarnell, from Pit 4, Square H-6. Pit 4 was $5 \mathrm{ft}$ in depth, $4 \mathrm{ft}$ in diam. Bottom lined with 
fired stones and hard black substance. Sample found at bottom of pit in direct association with thick and easily crumbled pottery.

M-1352. Rogers site, refuse pit

$\mathbf{5 0 0} \pm \mathbf{1 0 0}$

Charcoal, mostly ash, white oak and red oak groups, id. by R. Yarnell. Sample found 12 to 18 in. deep at base of refuse pit. Found in associated with thinner and better fired pottery than M-1351. Should date later.

\section{M-1353. Rogers site, Pit 5}

$2380 \pm 130$

Charcoal, some red oak, id. by R. Yarnell, from Pit 5 at depth of $6 \mathrm{ft}$. Pit was bell-shaped, $3 \mathrm{ft}$ in diam and $6 \mathrm{ft}$ deep. Sample was at base of pit in direct association with thick and easily crumbled pottery. General Comment (E.C.): M-1351 and M-1353 are acceptable and suggest contemporaneity between Hopewell and Adena here in Ohio basin. M-1352 is somewhat recent for pottery in association with sample. Assuming pottery not intrusive due to shallow refuse pit (12 to 18 in.), we would have a cultural sequence that extended into Fort Ancient aspect.

\section{Lower Mississippi, Southeast U. S.}

\section{M-1486. Cherry Valley mound group, Arkansas A.D. 1110}

$$
\mathbf{8 5 0} \pm 110
$$

Charred wood from Cherry Valley mound group $\left(35^{\circ} 26^{\prime} \mathrm{N}\right.$ Lat, $90^{\circ}$ 45’ W Long), NE1/4 Sec. 2, T9N, R3E, Mitchell Township, Cross Co., Arkansas. Sample from Mound Two, in entrance of burned house beneath mound. Site yielded new culture complex for NE Arkansas and is important because of remarkable resemblance of pottery vessels to beanpot shape found at Cahokia in Illinois. Cherry Valley may represent splinter group created by population increase at Cahokia (Michigan V, p. 37). Coll. 1958 and subm. by Gregory Perino. Comment (J.B.G.): this date more in line with other Middle Mississippi assays than earlier run of A.D. 700 .

\section{M-1446. Mounds Plantation, Louisiana}

$$
900 \pm 100
$$

Wood from Mounds Plantation (16 Cd-12), (38 $38^{\prime} \mathrm{N}$ Lat, $93^{\circ} 45^{\prime}$ $40^{\prime \prime} \mathrm{W}$ Long), Louisiana, ca. $2 \mathrm{mi} \mathrm{S}$ of Dixie, Louisiana and 10 to $12 \mathrm{mi}$ $\mathrm{N}$ of Shreveport, $1 \mathrm{mi} \mathrm{W}$ of Red River on W bank old Red River channel. Log No. 1 from Mound B, Burial 5, 20 in. above pit floor in fill forming frame above part of burial pit. Sherds in mound and site: Coles Creek, Alto, and Haley. Occupation late, with intrusive Belcher burial in mound top. Association in pit exclusively Alto-Gahagan. Gibson Aspect Caddoan, should date unassigned focus much like Alto and Gahagan. Same log sample dated by Univ. of Texas, sample Tx-55 at $860 \pm$ 120 (Texas II, p. 155). Coll. 1960 by R. McKinney; subm. by C. H. 
Webb, Shreveport, Louisiana. Comment (J.B.G.): agreement of Michigan and Texas dates would help place some part of Gibson aspect well within developed Middle Mississippi to north.

\section{Pinson site series, Tennessee}

Charred logs, white oak, id. by R. Yarnell, from Pinson site (Md 1), (35 29' $40^{\prime \prime} \mathrm{N}$ Lat, $88^{\circ} 40^{\prime} 55^{\prime \prime}$ W Long), Madison Co., Tennessee. Samples from post molds from floor of House 1, Area 2, located $1500 \mathrm{ft} \mathrm{SW}$ of Great Saul's mound. Should date house and associated sand and/or clay tempered pottery, the predominant ceramic assemblage at site (Fischer and McNutt, 1962). Coll. 1960 by F. W. Fischer and C. H. McNutt; subm. by F. W. Fischer for the McClung Mus., Knoxville, Tennessee.

M-1362A. Pinson site, House 1, Area 2

A.D. 1130

$$
820 \pm 110
$$

Charred wood from fill of post molds of House 1, Area 2.

\section{M-1362B. Pinson site, House 1, Area 2}

$1100 \pm 120$

Charred wood, a second sample, from collapsed wall or roof beams, of House 1, Area 2.

General Comment (F.W.F.): M-1362B coincides with recent extreme of our original estimate based upon apparently associated Miller II ceramics (Fischer and McNutt, 1961). Discrepancy between two dates may be explained in three ways. Samples may actually represent two noncontemporaneous structures. One or both samples may have been contaminated. Third explanation offered by G. H. McNutt: only one structure is represented and computation of the standard error of difference between these two assays (Spaulding, 1958) provides value of $t=1.72$. This indicates that difference in two dates is not significant at $\mathrm{p}=.05$ level, and suggests that two dates might be combined, giving average of A.D. $990 \pm 115$.

\section{Fatherland site series, Mississippi}

Charcoal, corncobs and cane from Fatherland site, Grand Village of the Natchez ( $31^{\circ} 32^{\prime} 45^{\prime \prime}$ N Lat, 91 $22^{\prime} 45^{\prime \prime} \mathrm{W}$ Long), Adams Co., Mississippi. Mound B is historically referable Great Sun's House of the Natchez Indians and was built in four stages. Stage IV falls within the French Colonial time period, 1682 to 1729 . M-1379 and M-1380 should reflect approximate beginning of the Natchez mound building occupation at site. Mound $\mathrm{C}$ is historic temple mound and is contemporaneous with Mound B, at least in its later phases. Also built in four stages, the last two supported temple structures (Albrecht, 1964; Neitzel, 1965). Coll. 1962 and subm. by R. S. Neitzel, Dept. of Archives and Hist., Jackson, Mississippi. 
M-1376. Mound A, Feature 101

A.D. 1570

$380 \pm 100$

Charcoal from Mound A, Feature 101, $8 \mathrm{ft}$ below surface. Grid location: N20-30, E80-90.

M-1377. Mound B, Feature 30

A.D. 1810

$140 \pm 100$

Burned clay and charcoal from Mound B, Feature 30 in Stage IV, $4.0 \mathrm{ft}$ depth. From bed of charcoal and fired plaster, 20 in. S of S40-W55, just under humus.

\section{M-1378. Mound B, Feature 7}

$425 \pm 100$

Burned cane and thatch from Mound B, Feature 7, at $2.6 \mathrm{ft}$ depth in S33.5-W40.6.

\section{M-1379. Mound B, Feature 7}

A.D. 1250

$700 \pm 110$

Charcoal from Mound B, Feature 7, an ash bed in S30-35, W50-55, floor of house structure $7.5 \mathrm{ft}$ below surface of mound on pre-French Stage II surface.

M-1380. Mound B, Feature 1

$770 \pm 110$

Charcoal from Mound B, Feature 1 in upper loading of Stage I, 9.0 $\mathrm{ft}$ below surface, S40-W90.

M-1381. Mound C, Feature 33

$725 \pm 110$

Charred corncobs from Mound C, Feature 33 from pit in house floor of Stage III, $3.8 \mathrm{ft}$ below surface, S630-640, W290-300.

M-1382. Mound C, Feature 30

A.D. 1270

$680 \pm 110$

Charcoal from Mound C, Feature 30, $2.0 \mathrm{ft}$ depth, S650-660, W270280.

M-1383. Mound C, Feature 44

A.D. 1430

Corncobs and charcoal from Mound C, Feature 44, $9.0 \mathrm{ft}$ depth, S630-640, W280-290, old humus layer beneath mound.

General Comment (R.S.N.): sample M-1383 from oldest surface beneath Mound C should be oldest sample in series, so something is obviously wrong. Otherwise series seems to be in order.

\section{M-1354. McLean mound, North Carolina}

$980 \pm 110$

Charcoal, pine, id. by R. Yarnell, from McLean mound $\left(35^{\circ} 05^{\prime}\right.$ $10^{\prime \prime} \mathrm{N}$ Lat, $78^{\circ} 51^{\prime} 12^{\prime \prime} \mathrm{W}$ Long), Cumberland Co., North Carolina. Sample, not burned in place, was located immediately over and touching unburned bones of bundle burial 78, at depth of 14 in. from top of mound and 16 in. from mound base in Square 21, Sec. 2. Should date 
near end of mound's use since sample occurs high in low circular sand mound, containing over 300 burials. McLean mound is first of class of mounds, found rather widely over coastal North and South Carolina, to yield charcoal for dating. Date should provide starting point for future work on a Late Woodland culture (plain and fabric impressed pottery, small triangular projectile points, stone pipes, and stone celts). Coll. 1961 and subm. by Lt. Col. H. A. MacCord, Richmond, Virginia. Comment (J.B.G.): this date appears satisfactory.

\section{M-1373. Holley Creek site, South Carolina}

$$
1890 \pm 130
$$

A.D. 60

Charred wood and nut shells from Holley Creek site $\left(33^{\circ} 19^{\prime} 10^{\prime \prime}\right.$ N Lat, $81^{\circ} 51^{\prime} 50^{\prime \prime}$ W Long), Aiken Co., South Carolina. Sample found in base of fire pit ca. 26 in. from ground surface. Will date Deptford culture. Coll. 1961 and subm. by W. F. Stiles, Mus. of the American Indian, New York City. Comment (W.F.S.): date is satisfactory for this Deptford complex.

\section{M-1557. Carters Dam site, Georgia}

$8380 \pm 130$

6430 в.c.

Charcoal from Carters Dam site (9 Mu 100) (34 $36^{\prime} 44^{\prime \prime} \mathrm{N}$ Lat, $84^{\circ} 41^{\prime} 22^{\prime \prime}$ W Long), Murray Co., Georgia. Sample found in Square A, at 66 to $72 \mathrm{in.} \mathrm{depth,} \mathrm{which} \mathrm{was} 1 \mathrm{ft}$ or more beneath 48 to $60 \mathrm{in.}$ zone of occupation representing Old Quartz layer defined by quartz ovate projectiles. Top 18 in. in profile represents Early Woodland including fiber-tempered and late Archaic defined by irregularly stemmed flint or chert projectiles. Late Archaic and Old Quartz levels are separated by sterile layer of homogeneous fluviatile sand. Coll. 1964 by John Wear; subm. by A. R. Kelly, Univ. of Georgia. Comment (J.B.G.): should indicate Old Quartz culture cannot be earlier than 6430 B.c., and thus does not intervene between the Pablo-Indian and Archaic occupation in the Southeast.

\section{Fort Center site series, Florida}

Wood and charcoal from the Fort Center site $\left(26^{\circ} 58^{\prime} \mathrm{N}\right.$ Lat, $81^{\circ}$ 26' W Long), 21/2 Sec. 29, R31E, T40S, W bank Fisheating Creek, Glades Co., Florida. Samples from collapsed and submerged charnel house. Wood carvings structure found at same level. Lack of ceramic change and trade sherds makes age estimate difficult. Platform pipes from deposit and earthworks suggest Hopewell. Charnel house apparently built in basin to facilitate flooding. Platform in building held burials and artifacts above high water. Coll. 1963 and subm. by W. H. Sears, Florida State Mus., Gainsville.

M-1599. Fort Center site

$1340 \pm 125$

Wood fragments associated with burials in charnel house. 


\section{M-1600. Fort Center site}

A.D. 1180

$770 \pm 100$

Wood fragments from deposit on floor of basin built to hold house. Sample in place when structure collapsed. Clay monitor pipes present.

\section{M-1601. Fort Center site}

$$
1920 \pm 100
$$

Wood and charcoal fragments from basin floor deposit and from certain burials, selected for improbability of intrusion.

General Comment (W.H.S.): dates satisfactory for this complicated site. Extensive excavations are planned for the immediate future.

\section{M-1598. Weeden Island site, Florida}

$1550 \pm 130$

Charcoal from Weeden Island site (Pi-1) $\left(27^{\circ} 45^{\prime} \mathrm{N}\right.$ Lat, $81^{\circ} 30^{\prime}$ W Long), T30S, R17E, Weeden Island on W shore of Tampa Bay, Florida. From wall of midden in lowest $1 \mathrm{ft}$ of $6 \mathrm{ft}$ thick shell midden. Level yielding sample is early occupation of site, possibly contemporaneous with burial mound excavated by Fewkes (1924). Coll. 1962 and subm. by W. H. Sears. Comment (W.H.S.): date is satisfactory.

\section{Northeast U. S., Canada}

\section{Martins Pond site series, Maryland}

Charred hickory nuts and charcoal from Martins Pond site $\left(39^{\circ} 00^{\prime}\right.$ $45^{\prime \prime}$ N Lat, $76^{\circ} 31^{\prime} 30^{\prime \prime}$ W Long), Anne Arundel Co., Maryland. Site on W end of Martins Pond. Coll. 1964 and subm. by H. T. Wright for Mus. of Anthropol., Univ. of Michigan.

\section{M-1605. Martins Pond site, Zone 2}

$$
1870 \pm 125
$$

A.D. 80

Charred hickory shells from Zone 2, S3E2-3, S/MP/Z, dark humic soil $6 \mathrm{ft}$ above sealevel covered by complex soil-colluvial series. Only material associated with Accokeek Cordmarked (Stephenson, Ferguson and Ferguson, 1963, p. 186-188) and Martins Pond complex. Should date 500 to 100 B.C.

M-1606. Martins Pond site, Zone 4

\section{A.D. 1900}

$$
50 \pm 100
$$

Charcoal from Zone $4, \mathrm{~S} / \mathrm{MP} / \mathrm{Z}$, in dark humic soil near top of complex soil-colluvial sequence $2 \mathrm{ft}$ below surface and $10 \mathrm{ft}$ above sealevel. Only available sample from Sullivan Cove phase and should date A.D. 500 to 1000 .

General Comment (H.T.W.): M-1605 is somewhat later than expected but is acceptable. M-1606 is substantially later than expected and has nothing to do with aboriginal occupants. 
M-1608. Luce Creek site, Maryland

$1370 \pm 120$

Charcoal from Luce Creek site $\left(39^{\circ} 00^{\prime} 15^{\prime \prime} \mathrm{N}\right.$ Lat, $75^{\circ} 31^{\prime} 00^{\prime \prime} \mathrm{W}$ Long), Anne Arundel Co., Maryland. Site on SE side of Luce Creek on Henry Mann estate. Sample found in shallow oyster midden, $80 \mathrm{ft}$ above sealevel. Will date Selby Bay phase and Mockley ware. Should be 200 B.C. to A.D. 300 (Stephenson, 1963, p. 189-190). Coll. 1958 and subm. by H. T. Wright for Mus. of Anthropol., Univ. of Michigan. Comment (H.T.W.): while somewhat later than expected, lateness seems to be true of most dates from group of samples in this area.

\section{M-1607. Ruf site, Maryland}

$2400 \pm 150$

Charcoal from Ruf site ( $38^{\circ} 56^{\prime} 50^{\prime \prime} \mathrm{N}$ Lat, $76^{\circ} 40^{\prime} 50^{\prime \prime} \mathrm{W}$ Long), Anne Arundel Co., Maryland. Site $4.0 \mathrm{mi}$ WNW of Davidsonville on Abends Bros. estate. Sample found in dark humic midden overlying reddish sand B' zone and overlain by plowed soil. From type site of Selby Bay phase (Mayr, 1958). Coll. 1941 by Thomas Mayr; subm. by H. T. Wright for Mus. of Anthropol., Univ. of Michigan. Comment (H.T.W.): date seems too early for this complex.

\section{M-1482. Killarney Bay I, Canada}

$1930 \pm 130$

Charcoal (cat. no. 39676) from Killarney Bay I $\left(46^{\circ} \mathrm{N}\right.$ Lat, $81^{\circ} 30^{\prime}$ W Long), Ontario, Canada. Found in Trench 3 in apparent steam bath, 24 to $25 \mathrm{ft}$ above Lake Huron's former $579.3 \mathrm{ft}$ level. Coll. 1953 and subm. by E. F. Greenman, Mus. of Anthropol., Univ. of Michigan. Comment (J.B.G.): date is satisfactory for this multi-component site.

\section{$2390 \pm 150$ \\ $2250 \pm 130$ \\ M-1528. Tanfield site (KdDq-7), Canada \\ 370 B.C.}

Charred animal fat, presumably seal blubber (Sample 3) from Tanfield site (KdDq-7) (62 $39^{\prime} \mathrm{N}$ Lat, 69 $37^{\prime} \mathrm{W}$ Long), Northwest Territories, at Cape Tanfield, Baffin Island. Mass of charred material flaked from heavily encrusted "cooking rock" at 8 in. depth below sod (total surface depth 14 in.). Site in "Tanfield Valley" $18 \mathrm{ft}$ above present highest tide, which, in this specific location, puts its chronological position early in Dorset sequence; typology agrees. Midden 18 to 22 in. deep, all except top 4 in. below sod permanently frozen. Covers est. $1100 \mathrm{sq} f t$ of which $80 \mathrm{sq} \mathrm{ft}$ excavated. No stratigraphic layers, apparently short occupation. Sample should provide important key to series of "Tanfield Valley" sites, of which 12 have been located from 11 to $50 \mathrm{ft}$ above sealevel. Seriated typologically in single continuum from what has been called pre-Dorset through Dorset period. Will cross-check part of sample sent to Univ. of Pennsylvania $\mathrm{C}^{14}$ lab. Est. age 600 to 300 B.C. (should be slightly more recent than T1 Site, Southampton Is.). Coll. 1962 by M. S. Maxwell; subm. for Maxwell by J. V. Wright, Natl. Mus. of Canada. 
Comment (M.S.M.): since this is a fragment of same sample sent for $\mathrm{C}^{14}$ analysis to Applied Sci. Center for Archaeol., age determination should ideally be same from Michigan and Pennsylvania labs. Ages arrived at by Univ. of Pennsylvania Lab. (P-698 and P-698A) are: 2594, 2618, 2628, and 2645 , all \pm 74 . Average age of these runs, based on half-life of 5568 and terminal date of A.D. 1950 would be 671 B.c. This date would be nearly identical with dates for similar assemblages at T-1 site. Southampton Island, and Alarnerk site, Igloolik. On basis of typological comparison, and other carbon dates, M-1528 and M-1528A seem 200 to $350 \mathrm{yr}$ too recent. Discrepancy can be resolved if Pennsylvania s.d. of 74 is subtracted from their most recent age determination, and Michigan s.d. of 130 is added to their oldest determination (M-1528); thus we arrive at same figure of 2520 B.P. Furthermore, if all assessments are averaged, we arrive at 2521 B.P., or 571 в.c. Dates from 500 to 700 B.c. would be most satisfactory from current archaeological interpretation. It should be kept in mind in age determinations in this series, that there are relatively few comparative assessments based on charred fat and that some of these have produced peculiar interpretive problems.

\section{M-1529. Sandy site (KdDq-2), Canada}

$1470 \pm 110$

Charcoal, predominantly driftwood, but with some indigenous Salix (Sample 9), from the Sandy site (KdDq-2) $\left(62^{\circ} 37^{\prime} \mathrm{N}\right.$ Lat, $69^{\circ}$ 32' W Long), Northwest Territories, at Juet Is. on S shore of Baffin Is. From 3rd or bottom layer of site, combined from 3 different squares. Each layer ca. 2.5 in. thick, separated by thin zones of sterile sand. Small habitation site $13.5 \mathrm{ft}$ above high tide (based on lowest point of growth of salt-intolerant lichen). Late in local Dorset sequence on basis of elevation and typology. Approx. $200 \mathrm{sq} \mathrm{ft}$ completely excavated 1960 to 1963. Should provide key point at most recent end of seriation of sites, and of typologies, which includes 38 sites on S coast Baffin Is. (lag between death of tree and drift to area should be taken into account). Est. age A.D. 200 to 400 . Coll. 1960 by M. S. Maxwell; subm. for Maxwell by J. V. Wright. Comment (M.S.M.): on basis of our current archaeological interpretation of seriation of site and assemblages on SE coast of Baffin Island, this is satisfactory date. Since age determination was based on charcoal, some of which may have come from old driftwood, cultural assemblage may be as much as 100 yr more recent, an age which would also be satisfactory. Significantly, date confirms our interpretation that in this specific region use of true stone burins (constituting $6 \%$ of total stone tool inventory of site) persists well into first millenium A.D.

$\begin{array}{lrr}\text { M-1530a. Avinga site (KdDq-8), Canada } & 2180 \pm 120 \\ 230 \text { B.c. } \\ 1790 \pm 120 \\ \text { M-1530b. Avinga site (rerun) } & \begin{array}{c}17 . D .160 \\ \text { Charred animal fat (Sample 27) from Avinga site }\end{array} \\ \text { N KdDq-8) }\left(62^{\circ}\right. \\ \text { N Lat, } 69^{\circ} 37^{\prime} \text { W Long), Northwest Territories, at Cape Tanfield, }\end{array}$


Baffin Is. Scraped from 6 small cooking rocks and 1 vessel fragment from various parts of site, all locations 8 or more in. beneath sod base, well into permafrost. Site in "Tanfield Valley," $33 \mathrm{ft}$ above highest tide. Lowest cultural material, at 16 in. below sod base, rests directly on water-washed beach sand. Limited testing indicates site covers at least $400 \mathrm{sq} \mathrm{ft}$ of which $200 \mathrm{sq} \mathrm{ft}$ excavated in 1963. Sample should provide important key to series of "Tanfield Valley" sites (12), and typological seriation of samples from 38 sites in general vicinity. Preliminary analysis of artifacts indicates intermediate period between what has formerly been considered pre-Dorset and Dorset. On basis of "Tanfield Valley" evidence, dividing point between the two appears to be presence of significant percentages of burins, burin-like tools, burin spalls and ground and polished slate knives, which at this site are respectively 8.11, 3.15, 9.46, and 9.01. Est. age 800 to 700 в.C. Coll. 1963 by M. S. Maxwell; subm. for Maxwell by J. V. Wright. Comment (M.S.M.): it seems virtually impossible that either age determination could date major assemblage of site. Subsequent analysis suggests that this is due to a number of factors, not least of which is sampling error. Since site contained no pieces of organic residue, and an age determination of assemblage was so critical in our seriation analysis, we scraped what carbon powder we could from a very few cooking rocks and one large lamp sherd. Scraping was done in open air, and we have now learned that concentrations of mold spores and pollen in air at that time of summer is very high. Conceivably this could be a source of contamination. Furthermore, analysis of field and laboratory data has virtually proved that lamp sherd, which contributed at least $75 \%$ of carbon, came from small pocket of late artifacts lying just beneath sod, and was separated from major component of site by 6 in. of sterile humus. Age differential between carbon taken from lamp sherd and that from cooking rocks is probably as much as $1000 \mathrm{yr}$.

\section{M-1531. Site KdDq-13, Canada}

$3480 \pm 200$

$$
1530 \text { B.C. }
$$

Charred animal fat dripped on sand (Sample 28) from Site KdDq$13\left(62^{\circ} 39^{\prime} \mathrm{N}\right.$ Lat, $69^{\circ} 37^{\prime} \mathrm{W}$ Long), Northwest Territories, at Cape Tanfield, Baffin Is. From 4 in. below surface, above permafrost. Site at $38 \mathrm{ft}$ elev on N-facing slope of "Tanfield Valley." Thinly occupied. Satisfactory camping location only if sealevel $35 \mathrm{ft}$ above present high tide. Site est. $1600 \mathrm{sq} \mathrm{ft}$ and $80 \mathrm{sq} \mathrm{ft}$ excavated. Assemblage appears intermediate between pre-Dorset and Dorset assemblages. Est. age 1000 B.c. (but based on inadequate amount of assemblage). Coll. 1963 by M. S. Maxwell; subm. for Maxwell by J. V. Wright. Comment (M.S.M.): very satisfactory date for camp site. Although cultural inventory recovered to date is small, elements of it demonstrate development of traits which become common in later Dorset sites. Typologically this agrees well with slightly later assemblage of Killilugak site dated $1093 \pm 63$ by Univ. of Pennsyvania (P-699). 


\section{M-1532a. Site KdDq-8-3, Canada}

$3880 \pm 150$

1930 B.C.

$\mathbf{3 8 5 0} \pm \mathbf{1 5 0}$

M-1532b. (rerun)

1900 B.c.

Charred animal fat cementing sand grains (Sample 29) from Site KdDq-8-3 (62 $39^{\prime} \mathrm{N}$ Lat, $69^{\circ} 37^{\prime} \mathrm{W}$ Long). Northwest Territories, at Cape Tanfield, Baffin Is. From 10 in. below sod base, below permafrost line. Site intensively occupied, small pocket in rocks at "Tanfield Valley," $27 \mathrm{ft}$ above sealevel. Cultural midden extending to $16 \mathrm{in}$. depth below sod base. Bottom of lowest cultural level rested on old sod surface. Site apparently first occupied some time after retreat of sea water from this level. Site not particularly valuable habitation location any time after retreat of sea water to $25 \mathrm{ft}$ level. Site est. to be $400 \mathrm{sq} \mathrm{ft}$, and 225 sq ft excavated. Sample should provide important key to what appears to be seriation of 12 sites in "Tanfield Valley." Assemblage should be early in Dorset continuum. Est. age 700 to 600 B.c. Should be slightly younger than T1 site, Southampton Is. Coll. 1963 by M. S. Maxwell; subm. for Maxwell by J. V. Wright. Comment (M.S.M.): major and probably only component of this small site falls within period of developed Dorset culture, and date for assemblage any earlier than 700 B.c. would do violence to interpretations of all archaeological investigators in E Arctic. Initial age determination of 1930 B.c. was so impossible that re-run was requested, which confirmed first determination. After analysis, I have resolved problem to my satisfaction. Field data indicates that charred animal fat sample came from same locally restricted zone (not more than two sq ft) as small sample of what appear to be very early stone tools. These artifacts were originally interpreted as persistent forms, but more detailed lab. analysis indicates that they are older than major part of assemblage. Since this is not enough to predicate an early component on, remaining assumptions are that sod shelters were used on site, as we use them today, that sod was cut from very early site and incorporated some artifacts and a lump of charred seal fat, which we were unlucky enough to select for dating site. Correlative information is: 1) sod is thicker on habitation sites due to increased nutrients in humus, and 2) there is pre-Dorset site (Loon site dated by Univ. of Pennsylvania, P-170-3590 \pm 63 B.P) 50 yd from where charred fat was recovered. Unfortunately this situation raises some doubts about other sites in immediate vicinity and will be closely investigated.

\section{M-1533. Kiliktee site (KdDq-19), Canada $\quad$ A.D. 280}

Charred animal fat dripped on sand, cementing sand grains (Sample 30), from Kiliktee site (KdDq-19) (62 $52^{\circ} 58^{\prime} \mathrm{N}$ Lat, 69 $40^{\prime} \mathrm{W}$ Long), Itivirk Bay, Baffin Is., Northwest Territories. Depth 4 in. beneath sod base, well above permafrost line. Small site, possibly no more than two tent rings. Elevation est. at $14 \mathrm{ft}$ above present high tide. Located within boundaries of Kiliktee's winter camp, and $80 \%$ of artifacts coll. by 
members of Kiliktee's family. Area $15 \mathrm{ft}$ by $35 \mathrm{ft}$ excavated, cultural layer only 4 to 6 in. thick. Sample should provide important terminal date for Dorset culture of 38 site pre-Dorset-Dorset continuum in the Lake Harbor region. Part of continuum recognized in "Tanfield Valley" although $5 \mathrm{mi} \mathrm{N}$ of that location. Est. age A.D. 300 to 400 . Typology and elevation suggest contemporaneity with Aberjar site, Igloolik, Northwest Territories. Coll. 1963 by M. S. Maxwell; subm. for Maxwell by J. V. Wright. Comment (M.S.M.): this age determination fits in very well with our typology seriation from vicinity of Lake Harbour, Baffin Island.

\section{M-1534. Site KdDq-8-2, Canada}

$2200 \pm 120$

250 B.C.

Charred fat dripped on sand grains, cementing them together (Sample 32) from Site KdDq-8-2 (62 $39^{\prime} \mathrm{N}$ Lat, 69 $37^{\prime} \mathrm{W}$ Long), Northwest Territories, at Cape Tanfield, Baffin Is. From 8 in. beneath sod base, 2 in. below permafrost line. Very rich midden, 14 to 16 in. deep in "Tanfield Valley," 31 ft above present high tide. Site covers est. 400 sq ft and $150 \mathrm{sq} \mathrm{ft} \mathrm{excavated.} \mathrm{Artifacts} \mathrm{intermediate} \mathrm{between} \mathrm{pre-Dorset}$ and Dorset. Sample should provide key to interpreting 12-site preDorset-Dorset continuum in "Tanfield Valley," and 38-site Dorset continuum in region of $\mathrm{S}$ Baffin Is. Est. age 800 to 700 B.C. In terms of typology, elevation, and sod cover above base sand, should be 50 to 100 yr more recent than Site KdDq-8. Coll. 1963 by M. S. Maxwell; subm. for Maxwell by J. V. Wright. Comment (M.S.M.): despite wide discrepancy between est. age of sample and age determination, est. age was based on preliminary analysis of data, and age determination of 250 B.c. is satisfactory for part of site. There is no discernible sterile zone between two components; however, they were laid down under markedly different climatic conditions. M-1534 provides satisfactory date for more recent component and habitation of site in warmer times. Older component, culturally richer and therefore giving impression of greater age to total site, is still thought to date between 800 B.c. and 600 B.c.

\section{M-1535. Nanook site (KdDq-9-1), Canada}

$2410 \pm 120$

Charred animal fat cementing sand grains and pieces of seal skin (Sample 33) from Nanook site (KdDq-9-1) $\left(62^{\circ} 39^{\prime} \mathrm{N}\right.$ Lat, 69॰ $37^{\prime} \mathrm{W}$ Long), Northwest Territories, at Cape Tanfield, Baffin Is. From 12 in. beneath sod base. Area of site est. at $3600 \mathrm{sq} \mathrm{ft}$ and $325 \mathrm{sq} \mathrm{ft}$ excavated. Midden 20 to 24 in. deep, all except top 6 in. in permafrost. Lack of drainage makes possible contamination by modern microorganisms. Should be slightly more recent than sample from Site KdDq-9, Component 2 (under analysis by Univ. of Pennsylvania lab.). Not beach site Probably occupied in winter at time when sealevel almost $25 \mathrm{ft}$ higher than present. Typology fits into 12-site continuum for "Tanfield Valley." Est. date 700 to 600 B.c. Typology suggests coeval with Site KdDq-8-3. Actual elevation of site $40 \mathrm{ft}$. Coll. 1963 by M. S. Maxwell; subm. for 
Maxwell by J. V. Wright. Comment (M.S.M.): date of 460 B.c. seems 400 yr too early, not on basis of est. age, but on basis of Univ. of Pennsylvania dates for what has been thought to be simply another part of same site $20 \mathrm{ft}$ to SW. From this latter location, identified as KdDq-9-2, willow twings in permafrost at a depth of 6 to 8 in. were $1840 \pm 53$ B.P., and sod buried in permafrost between two cultural layers was $1929 \pm 53$ B.P. (P-706 and P-704). In field these two excavation units were treated separately, but analysis of field and lab. data has indicated their virtual identity, both qualitatively and quantatively. Furthermore, KdDq-9-2 are equally unique in having so few soapstone lamp sherds that they constitute less than $1 \%$ of artifact inventory-suggesting occupation either in warm seasons and/or warm yr. Admittedly, sample M-1535 comes from deeper in midden. One solution to problem is that sufficient cultural conservatism on this site, occupied only in summer months over $500 \mathrm{yr}$ span, would not display marked stylistic differences in kind or relative frequency of tools (this is not at variance with my basic contention that in this series of 38 sites spanning $3000 \mathrm{yr}$, process of cultural change as reflected by artifacts is remarkably slow). Another possible solution is more critical because it throws doubts on majority of dates from Lake Harbour vicinity. It should be noted that more recent dates (P-704 and P-706) are based on samples of sod and willow twigs, whereas older date is based on charred fat (presumably seal blubber) and seal skin (M1535). At Port aux Choix site Elmer Harp (pers. commun.) has found that with regularity charred seal fat dates and charcoal dates from same houses vary by nearly same order of magnitude, with seal fat always older than charcoal dates.

\section{U. S. Great Plains}

\section{M-1368. Burkett site, Nebraska}

A.D. 1630

$320 \pm 100$

Charcoal (No. 590) from Burkett site (25NCl) $\left(41^{\circ} 25^{\prime} 16^{\prime \prime} \mathrm{N}\right.$ Lat, $97^{\circ} 47^{\prime} 35^{\prime \prime}$ W Long), Nance Co., Nebraska. NE1/4 Sec. 29, T17N, R4W. Sample found in storage pit intrusive in refuse deposit. Site is of Lower Loup focus, and specimen should date middle occupation of site. Should be ca. A.D. 1500 to 1650: Protohistoric Pawnee (Dunlevy, 1936; Grange, 1962). Coll. 1940 by A. T. Hill; subm. by M. F. Kivett, Nebraska Hist. Soc., Lincoln, Nebraska. Comment (M.F.K.): date is acceptable but somewhat late in terms of previous estimates and relative amounts of contact materials. Date of 1530 would be more satisfactory in my opinion.

\section{M-1369. Wright site, Nebraska}

$270 \pm 100$

Charcoal (No. 161) from Wright site (25 Nc3) (41 26 21" N Lat, $97^{\circ} 45^{\prime} 25^{\prime \prime}$ W Long), Nance Co., Nebraska. NW1/4 Sec. 23, SE $1 / 4$ Sec. 15, $\mathrm{NE} 1 / 4$ Sec. 22, T17N, R4W. Sample found in House 5 on floor with 50 scattered human skeletons, interpreted as evidence of attack on village. 
Wright site is of Lower Loup focus. Should date middle occupation of site. Should be ca. A.D. 1650 to 1750: Protohistoric Pawnee (Grange, 1962; Kivett, 1958). Coll. 1936 by A. T. Hill and George Lamb; subm. by M. F. Kivett. Comment (M.F.K.): date is in agreement with previous estimates based on artifact inventory. Trade goods are relatively common in comparison to Burkett site.

\section{Western U. S.}

\section{Wilson Butte cave series, Idaho}

Bone from Wilson Butte cave $\left(42^{\circ} 45^{\prime} \mathrm{N}\right.$ Lat, $114^{\circ} 15^{\prime} \mathrm{W}$ Long), Jerome Co., Idaho. Coll. 1959 and 1960 by Ruth Gruhn; subm. by E. H. Swanson, Idaho State Univ. Mus., Pocatello, Idaho.

\section{M-1409. Wilson Butte cave, Stratum C}

$\mathbf{1 4 , 5 0 0} \pm 500$

Bone from Wilson Butte cave, Stratum C, lower zone of grey/brown sand. A pooled sample, from Square $T_{8} S_{5}$ (depth 160 to $200 \mathrm{~cm}$ below $\mathrm{T}_{8} \mathrm{~S}_{6}$ ), Square $\mathrm{T}_{11} \mathrm{~S}_{2}$ (depth 210 to $280 \mathrm{~cm}$ below St. $\mathrm{T}_{11} \mathrm{~S}_{2}$ ), and Square $\mathrm{T}_{11} \mathrm{~S}_{4}$ (depth 220 to $320 \mathrm{~cm}$ below St. $\mathrm{T}_{11} \mathrm{~S}_{4}$ ). Sample should date early period of deposition of grey/brown sand. Character of sediment and microfaunal remains indicates cool moist climate. Should date ca. 8000 to 9000 в.c. Extinct fauna: horse, camel, sloth. Associated artifacts: Assemblage I (Gruhn, 1961).

\section{M-1410. Wilson Butte cave, Stratum E}

Bone from Wilson cave, Stratum E, yellow/brown clay. Square $\mathrm{T}_{9} \mathrm{~S}_{1}$, depth 200 to $300 \mathrm{~cm}$ below $\mathrm{St}$. $\mathrm{T}_{8} \mathrm{~S}_{1}$. Earliest deposit in cave and expected to antedate 10,000 B.c. Microfaunal remains indicate cool moist climate. Extinct fauna; horse, camel, and possibly bird. Associated artifacts: two fragments of bone with cuts marks.

General Comment (R.G.): since artifacts are associated, these dates place Wilson Butte cave among earliest dated archaeological sites in North America (Gruhn, 1961).

\section{M-1466. 18 Mile Bend Site, New Mexico}

$820 \pm 110$

Bison bone from P4B (Mesita Negra phase) component of L8 Mile Bend site $\left(34^{\circ} 14^{\prime} \mathrm{N}\right.$ Lat, $104^{\circ} 13^{\prime} \mathrm{W}$ Long), De Baca Co., New Mexico. From Trench 2 at 8 to 10 in. level (Jelinek, 1960). Coll. 1960 and subm. by A. J. Jelinek, Mus. of Anthrop., Univ. of Michigan. Comment (A.J.J.): date as expected on basis of intrusive Anasazi ceramics.

\section{Mexican, Central South America}

\section{La Quemada series, Mexico}

Charcoal and wood from La Quemada $\left(22^{\circ} 27^{\prime} \mathrm{N} \mathrm{Lat,} 102^{\circ} 49^{\prime} \mathrm{W}\right.$ Long), State of Zacatecas, Mexico. Should date building and destruction 
of a number of conjoined rooms on SE side of acropolis. Samples from same room as M-430 and M-331 (Michigan II). Coll. 1964 by Ignacio Armillas and Peter Taylor; subm. by Pedro Armillas, Southern Illinois Univ.

M-1651. La Quemada, Room 3

$1230 \pm 120$

Charcoal (LQW1) found in rubble filling Room 3, above adobe floor and 1.56 in. below datum. Probably fragment of charred beam. Should date construction of roof.

M-1652. La Quemada, Room 4

$$
1540 \pm 120
$$

Wood (LQW22) from beam above floor of Room 4, one of several partially turned parallel beams that had supported adobe roof.

\section{M-1653. La Quemada, Room 4}

$1230 \pm 120$

Charcoal (LQW35) from $\mathrm{N}$ post, one of two posts that supported roof of room. Stumps were found under debris of roof. Should date construction of room and be roughly contemporary with M-1652 and M-1654.

\section{M-1654. La Quemada, Room 4}

Wood (LQW38) from S post, Room 4.

\section{M-1655. La Quemada, Room 4}

Charcoal (LQW13 and LQW28) lying in rubble on hard adobe assumed to be upper surface of roof in Room 4, from Excavation Blocks 1 to 5 .

\section{M-1656. La Quemada, Room 4}

Small charcoal sample (LQW25) lying in rubble of Room 4 from Excavation Blocks 3, 4, and 5.

\section{M-1658. La Quemada, Room 4}

$$
1020 \pm 120
$$

Charcoal from hearth in rubble of Room $4,50 \mathrm{~cm}$ above upper surface of fallen roof and $50 \mathrm{~cm}$ below present ground. Several stones placed in circle (diam $1 / 2 \mathrm{~m}$ ) around fire. Animal bones and broken pot in same general area. Definitely post-dates destruction of house, but does not necessarily date event. Fire may have been lit long after building was ruined.

General Comment (J.B.G.): dates conform with archaeological interpretations.

\section{La Presa de Ambosco series, Mexico}

Charred beans and corn from La Presa de Ambosco $\left(22^{\circ} 27^{\prime} \mathrm{N}\right.$ Lat, $102^{\circ} 49^{\prime}$ W Long), State of Zacatecas, Mexico. A village site located on 
plain of Malpaso River Valley, $6 \mathrm{~km}$ from La Quemada to SW. Coll 1964 and subm. by Pedro Armillas.

\section{M-1659. La Presa de Ambrosco, House 2 A.D. 950}

$1100 \pm 120$

Charred beans from House 2, Bin 2, one of twin sunken bins adjacent to house; bottoms and walls of these pits were plastered with hard adobe.

M-1660. La Presa de Ambrosco, House 2

$960 \pm 110$

Charred corn seeds from House 2, Bin 1.

A.D. 990

General Comment (J.B.G.): dates conform with archaeological interpretations.

\section{M-1580. Mejicanos site (Site C), Guatemala A.D. 650}

$$
1300 \pm 130
$$

Shell, Spondylus princeps Broderip, from Mejicanos site $\left(14^{\circ} 25^{\prime} \mathrm{N}\right.$ Lat, $90^{\circ} 34^{\prime} \mathrm{W}$ Long), on $\mathrm{S}$ shore of Lake Amatitlán, Guatemala, adjacent to Lavadores underwater site $1 \mathrm{~A}$ and 1B. Sample found in cache in mound inside Esperanza fleshware cylindrical tripod vessel, with jadeite bead. Traditional date for ware is A.D. 300 to 600. Underwater archaeological specimens from Lavadores appear to be mostly Esperanza types (Middle Classic). Date from Mejicanos will therefore help date Lavadores underwater archaeological complex (Borhegyi, 1960). Coll. 1963 and subm. by S. F. Borhegyi, Milwaukee Public Mus., Milwaukee, Wisconsin. Comment (S.F.B.): date is satisfactory.

\section{Africa, Europe, Siberia}

\section{Gebel Silsileh series, Egypt}

Charcoal from Locality III at Gebel Silsileh $\left(24^{\circ} 28^{\prime} \mathrm{N}\right.$ Lat, $32^{\circ} 57^{\prime}$ E Long), near Kom Ombo, Upper Egypt. Charcoal was collected from uppermost of two archaeological levels in stratified site ca. $4 \mathrm{~km}$ from present Nile. Site has been buried in late Pleistocene Nile silts. Charcoal was associated with Late Pleistocene industry, the Sebekian, in occupation level rich in faunal materials and artifacts. Present dates were run to assist in checking discrepancies in dates from Michigan and Isotopes Inc. labs. (Smith, 1964; Crane and Griffin, 1965). Site was investigated by Canadian Prehistoric Expedition to Nubia for Natl. Mus. of Canada. Coll. 1963 and subm. by P. E. L. Smith, Univ. of Toronto.

\section{M-1641. Gebel Silsileh, Locality III, $\quad 13,611 \pm 600$ Square 14-J, Level 1

Charcoal from Square 14-J, Level 1, upper part, associated with flint tools of Sebekian culture and animal bones. 
M-1642. Gebel Silsileh, Locality III, Squares 17-0 and 18-O

$15,200 \pm 700$ 13,250 в.c.

Charcoal from Squares 17-0 and 18-0, a hearth area, and associated with Sebekian flints and animal bones.

General Comment (P.E.L.S.): reasons for the discrepancies are not clear.

\section{Monastery of St. Catherine series, Egypt}

Wood from Church of the Transfiguration in Monastery of St. Catherine ( $28^{\circ} 44^{\prime} \mathrm{S}$ Lat, $34^{\circ} 00^{\prime} \mathrm{E}$ Long), Sinai Peninsula, Egypt. Coll. 1960 and 1963 and subm. by G. H. Forsythe, Kelsey Mus., Univ. of Michigan.

M-1673. Church of the Transfiguration nave A.D. 515

$$
1435 \pm 120
$$

Wood from truss of roof over nave of church. From diagonal strut against king post. Roof of central nave is unique example of Byzantine carpentry. Once sheathed with lead plates, its stout struss construction is still in perfect condition. One of lower chords bears inscription of Emperor Justinian which appears to date chord between A.D. 548 and 565 .

M-1674. Church of the Transfiguration nave A.D. 735

$1215 \pm 120$

Wood from truss of roof over nave of church. Sample is from side board against lower chord of truss.

M-1675. Church of the Transfiguration nave A.D. 635

$1315 \pm 120$

Wood from truss of roof over nave of church. Sample is from decorative molding applied to lower chord of truss.

\section{M-1676. Church of the Transfiguration gable A.D. 250}

$$
1700 \pm 120
$$

re-run $1500 \pm 120$

A.D. 450

Wood from part of chassis used to hold in position circular window (oculus), composed of glass panes set in plaster at $\mathrm{E}$ end of church in a gable. On basis of other structural and archaeological evidence, this appears to be Byzantine window of sixth century A.D. still in situ, and therefore earlier by $500 \mathrm{yr}$ than other comparable windows now in place.

\section{M-1677. Church of the Transfiuration nave A.D. 1800}

$$
150 \pm 100
$$

$$
\text { re-run } \quad 0 \pm 100
$$

Wood from truss of roof over nave of church. Sample is from $\mathrm{N}$ end of lower chord.

General Comment (G.H.F.): dates seem to be reasonable except for M-1677 which should not be modern. Additional comparable specimens will be run in the future. 
Date lists:

REFERENCES

Michigan V Crane and Griffin, 1960

Michigan IX Crane and Griffin, 1964

Texas II Tamers, Pearson and Davis, 1964

Yale VII Stuiver and Deevey, 1962

Yale VIII Stuiver, Deevey and Rouse, 1963

Albrecht, A. C., 1944, The location of the historic Natchez villages: Jour. Mississippi Hist., v. 6, no. 2, p. 67-89.

Bell, R. E., 1953, Pottery vessels from the Spiro Mounds: Oklahoma Anthrop. Soc. Bull., no. 1, p. 25-38.

Binford, L. R., 1963a, The Hodges site, a late archaic burial station: Anthropol. Papers, Mus. of Anthropol., Univ. of Michigan, no. 19, p. 124-148.

1963b, The Pomranky site, a late archaic burial station: Anthropol. Papers, Mus. of Anthropol., Univ. of Michigan, no. 19, p. 149-192.

Borhegyi, S. F. de, 1960, Pre-Columbian cultural connections between Meso-America and Ecuador: Mid. Am. Res. Rec., v. 2, no. 7.

Broecker, W. S., and Farrand, W. R., 1963, Radiocarbon age of Two Creeks forest bed, Wisconsin: Geol. Soc. Bull., v. 74, p. 795-802.

Campbell, T. E., 1961, Caddoan radiocarbon dates: Bull. Texas Archaeol. Soc., no. 31, p. $145-151$.

Crane, H. R., 1961, The $\mathrm{CO}_{2}-\mathrm{CS}_{2}$ geiger counter: Rev. Sci. Instruments, v. 32, p. 953.

Crane, H. R., and Griffin, J. B., 1960, University of Michigan radiocarbon dates V: Am. Jour. Sci. Radioc. Supp., v. 2, p. 31-48. p. $1-24$

DeJarnette, D. L., Kurjack, E. B., and Cambron, J. W., 1962, Excavations at the Stanfield-Worley Bluff Shelter: Jour. Alabama Archaeol., v. 8, no. 1 and 2.

Dreimanis, Aleksis, 1964, Lake Warren and Two Creeks interval: Jour. Geol., v. 72, p. $247-250$.

Dunlevy, M. L., 1936, A comparison of the cultural manifestations at the Burkett and the Gray-Wolfe site: Chap. Nebraska Archaeol., v. 1, p. 147-248.

Fewkes, J. W., 1924, Preliminary archaeological explorations at Weeden Island, Florida: Smith. Misc. Coll., v. 76, no. 13, p. 1-26.

Fischer, F. W., and McNutt, C. H., 1962, Text excavations at Pinson mounds, 1961: Tennessee Archaeol., v. 18, no. 1, p. 1-13.

Fitting, J. E., 1965, Late woodland culture of southeastern Michigan: Anthropol. Papers, Mus. of Anthropol., Univ. of Michigan, no. 24.

in press, Radiocarbon dating the Younge tradition: Am. Antiquity, v. 32 , no. 2 .

Grange, R. T., Jr., 1962, Ceramic relationships in the central plains: Univ. of Arizona, unpub. dissertation.

Gruhn, Ruth, 1961, The archacology of Wilson Butte cave, southcentral Idaho: Occas. Papers, Idaho State College Mus., no. 6.

Hough, J. L., 1953, The prehistoric Great Lakes of North America: Am. Sci., v. 51, no. 1, p. $84-110$.

Hurt, W. R., 1961, Archaeological work at the Tabor and Arp sites: Mus. News, W. H. Over Mus., Vermillion, South Dakota, v. 22, no. 8, p. 1-6.

1963, The 1962 excavations of the Sherman Park Mound site, $39 \mathrm{MN} 8$, a newly radiocarbon date site in South Dakota: Mus. News, W. H. Over Mus., Vermillion, South Dakota, v. 24, no. 1, p. 1-4.

Jelinek, A. J., 1960, An archacological survey of the middle Pecos River and the adjacent Llano Estacado: Univ. of Michigan, Univ. Microfilms, Ph.D. dissertation.

Kivett, M. F., 1958, The Oacoma site, Lyman County, South Dakota: ms., Nebraska State Hist. Soc.

Mayr, Thomas, 1958, The Ruf site: and influence from Pennsylvania: Eastern States Archaeol. Fed. Bull., no. 17, p. 15.

Neitzel, R. S., Archeology of the Fatherland site: The Grand Village of the Natchez: Anthropol. Papers of Am. Mus. Nat. Hist., v. 51, pt. 1.

Nuckolls, J. B., 1958, The Pinsons Mounds: Tennessee Archaeol., v. 14, no. 1, p. 1-8.

Oltz, D. F., and Kapp, R. O., 1963, Plant remains associated with mastodon and mammoth remains in central Michigan: Am. Mid. Nat., v. 70, no. 2, p. 339-346. 

Orr, K. G., 1946, The archaeological situation at Spiro, Oklahoma, a preliminary
report: Am. Antiquity, v. 11, no. 4, p. 228-255.

United States, ed. by J. B. Griffin, p. 239-256.

Phillips, Phillip, Ford, J. A., and Griffin, J. B., 1951, Archaeological survey in lower Mississippi alluvial valley, 1940-1947: Papers of Peabody Mus. of Am. Archaeol. and Ethnol., Harvard Univ., v. 25, p. 195-147.

Smith, P. E. L., 1964, Radiocarbon dating of a Late Paleolithic culture from Egypt: Science, v. 145 , p. 811 .

Spaulding, A. C., 1958, The significance of differences between radiocarbon dates: Am. Antiquity, v. 23, no. 3, p. 309-311.

Stephenson, R. L., Ferguson, A. L. L., and Ferguson, H. G., 1963, The Accokeek site, a middle Atlantic seabord culture sequence: Anthropol. Papers, Mus. of Anthropol., Univ. of Michigan, no. 20.

Stuiver, Minze, and Deevey, E. S., 1962, Yale natural radiocarbon measurements VII: Radiocarbon, v. 4, p. 250-262.

Stuiver, Minze, Deevey, E. S., and Rouse, I., 1963, Yale natural radiocarbon measurements VIII: Radiocarbon, v. 5, p. 312-341.

Swanson, E. H., Jr., Butler, R., and Bonnichen, R., 1964, Birch Creek papers no. 2, natural and cultural stratigraphy in the Birch Creek Valley of eastern Idaho: Papers of the Idaho Univ. Mus., Moscow, Idaho, no. 14

Tamers, M. A., Pearson, F. J., Jr., and Davis, Mott E., 1964, The University of Texas radiocarbon dates II: Radiocarbon, v. 6, p. 138-159.

Washburn, A. L., and Stuiver, Minze, 1962, Radiocarbon dated postglacial delevelling in northeast Greenland and its implications: Arctic, v. 15, p. 66-73.

Wedel, Waldo R., 1943, Archeological investigations in Platte and Clay counties, Missouri: Smithsonian Inst., U.S. Natl. Bull. no. 183. 